\title{
Civil Military Relations in a Post-Colonial State: An Interrogation of Nigeria's Military Internal Operations
}

\author{
Chukwuemeka Enyiazu1 ${ }^{*}$, Onyedikachi Madueke², Casmir Chukwuka Mbaegbu ${ }^{3}$ \\ ${ }^{1}$ Department of Political Science, Abia State University, Uturu, Nigeria \\ ${ }^{2}$ Department of Politics and International Relations, University of Aberdeen, Aberdeen, United Kingdom \\ ${ }^{3}$ Department of Political Science, University of Nigeria, Nsukka, Nigeria \\ Email: ${ }^{\star}$ Chukwuemeka.enyiazu@abiastateuniversity.edu.ng
}

How to cite this paper: Enyiazu, C., Madueke, O., \& Mbaegbu, C. C. (2022). Civil Military Relations in a Post-Colonial State: An Interrogation of Nigeria's Military Internal Operations. Open Journal of Political Science, 12, 162-180.

https://doi.org/10.4236/ojps.2022.122010

Received: November 4, 2021

Accepted: February 28, 2022

Published: March 3, 2022

Copyright $\odot 2022$ by author(s) and Scientific Research Publishing Inc. This work is licensed under the Creative Commons Attribution International License (CC BY 4.0).

http://creativecommons.org/licenses/by/4.0/

\begin{abstract}
The current corps of Nigerian army are products of top tertiary military and policy institutions. They have demonstrated their prowess internationally, especially, in peace keeping and peace enforcement. Forty-four years (44 yrs) after the Nigerian Afro-Beat Maestro (Fela) sang, “...they leave sorrow, tears and blood...", the Nigerian army is still riveted in gross human rights abuses. Recently, it is competing with Boko Haram on who comes first on the list of International Criminal Court's (ICC) human rights abuses. Given that the army is trained to use maximum force and the fact that post-colonial states' crises, especially in Africa, and specifically Nigeria are internal. There has been the debate on the establishment of medium force outfit in Nigeria, which led to the establishment and subsequent disbandment of National Guard in the 1990s. The debate continued to rage in this Fourth Industrial Revolution era. But the cost implication of running such a paramilitary outfit has posed a major hindrance. To fill this gap, this paper joins the debate and argues for the establishment of an Army Constabulary Corp (ACC), a medium force between the army maximum force and the police minimum force. The paper uses the Feaver Agency theory of civil military relation as its theoretical framework. The study collated data through documentary methods. In analysing the data, the qualitative data were transcribed, interpreted, and analysed through systematic logical inductions.
\end{abstract}

\section{Keywords}

Human Rights Abuses, ICC, Medium Force, Army Constabulary Corps 


\section{Introduction}

In 1977, the late Nigerian Afro-Beat legend and Nigerian Music Maestro Fela Kuti released an album on the invasion of his Kalakuta Republic House by the Nigerian Army (NA) with the lyrics, “...the leave sorrows, tears and blood... their regular trade mark..." Forty-four years after, Nigeria with high calibre soldiers trained in Nigeria Defence Academy (NDA), Nigeria War College, Institute of Policy and Strategic Studies (NIPSS) and other top institutions in Nigeria and overseas, is still competing with a ragtag Boko Haram insurgent group on who comes top on human rights abuses on International Criminal Court (ICC) table.

Indeed, from 1999, the NA has grossly abused the rights of Nigerian citizens in Odi in November 1999; in Zaki-Biam, Pro-Biafra advocates on May 30, 2016; hundreds of Islamic Movement in Nigeria (IMN) members, also known as Shi'ites were massacred in Zaria and soldiers used live ammunition between October 27 and October 29, 2018, and admitted to killing six of their members (Ojo, 2009; Enyiazu, 2018). Enyiazu et al. (2021: p. 15) noted:

On October 20, 2020, shortly before 7 p.m., EndSARS demonstrators while singing Nigeria's national anthem; soldiers walk toward the protesters with a terrifyingly casual calm, the kind of calm you cannot have if you are under attack, and they shoot, not up in the air, which anyway would still be an atrocity when dealing with peaceful protesters, but with their guns at arm level, shot to kill. Flashes of gunfire tainted the air; but their felling in a hail of soldiers' bullets, under the shield of darkness, should shake Nigeria to its core. Leaving a number of people dead and flags stained with blood; filling Nigerian social-media feeds with images that prompted condemnation from around the world.

The frequency of using the military to settle internal disputes compounds the problem of violence in the Nigeria's nascent democracy. The consequence of which is the violation of rights of Nigerians, the bait for a culture of violence and a continuation of the ethos 29 years of military dictatorship and absolutism which employed violence against the civil society (Ojo, 2009). Ake (1995: p. 34) observed that the military and democracy are in dialectical opposition. The military is an apparatus for war; force is its language and style. Hence, their being used unduly militarizes political and civil conflicts.

Indeed, the need for a medium security force is a known security gap in Nigeria. General Ibrahim Babagida's military government was the first to problematize the need of a medium force outfit, because of frequent border skirmishes between NA and Cameroonian Gendarme (a medium force), which ordinarily would have been mere border skirmishes but were always escalated because of the involvement of the Nigerian army. To fill the gap, the National Guard was established in 1991; the succeeding General Abacha's regime disbanded it. Vanguard Editorial (November 9, 2010), noted the return to this idea by former 
President Goodluck Jonathan, following acts of terrorism and communal violence in some parts of the country in 2010. These are clear indications that there is the awareness that the army is trained to fight war against enemies and is not suited for internal security against citizens.

The NA is aware that it is not fit for internal operations with the frequent resultant human rights abuses and its consequent NA battered image; thus, its selfdirected reforms, Transformation Agenda, implemented from 2010 to 2014. Events in Zaria and Abuja with Shiites; in South East with IPOB and the EndSARS shooting at Lekki; show that the army cannot give what it does not have: sledge hammer is not an instrument to kill flies. The army is instituted to see any opposition as enemy to crush.

Meanwhile, consequent upon the abuse of rights of Nigerian by the army in lieu of the army being an institution that sees any opposition as an enemy to crush and is the coming into existence of concepts like Responsibility to Protect (R2P) and other multilateral regimes that guide and place consequences on military operations. Nigeria is signatory to them, and it mandates Nigeria to abide by the rules.

Using Feaver model of principal-agent civil military theory, especially its means of monitoring (fire alarms), which questions the behaviour of the agent (army) through platforms like think tanks, media, and international organisations and enables the principal (government) to control and even reform the agent (Feaver, 2005: pp. 76-85; Baker, 2007). This paper focuses on International military operational Regimes and the consequence of its continued fissure by the Nigerian military. The litany of abuses by the NA is well documented in literature, thus we shall briefly grasp through it and argues that the foundation of the Nigerian military predispose it to human rights violation in internal security operations, and rather than the continued running afoul of International regimes on military operation, the paper argues for the establishment of a Nigerian Army Medium Force named Constabulary Corps, which shall emphasise proportionality, as opposed to army disproportionate use of force; and (shall be)based on the intermediate spectrum of force (army-maximum and police-minimum).

This paper, apart from the introduction and conclusion, has five other sections: Nigerian army and civil military relations; theoretical perspective; military operational regimes; Nigeria army civil military reforms and the case for an Army Constabulary Corp.

\section{Nigerian Army and Civil Military Relations}

The NA is historically rooted in the colonial Royal West African Frontier Force (RWAFF), which was disbanded in 1959 (Aboagye, 1999 cited in Salihu, 2017). Thus, NA emerged from a colonial army that was created for the purposes to quell indigenous resistance and serve the interests of colonial powers (Salihu, 2017). The post-colonial civil-military relation in Nigeria is influenced by their 
colonial history (Naison Ngoma cited in Salihu, 2017), which is a security culture within which the tradition is one of repressive coercion and general lack of civility towards the civilian population with reckless disregard for the rights of the people (Ibrahim, 2017). It was institutionalised to the detriment of democratic civil-military relations.

Military takeovers became commonplace in Africa in the 1960s and 1970s and Nigeria was no exception (Ebo, 2005). Indeed, the Military ruled Nigeria for 29 out of the 60 years of its existence and impacted strongly on the country's culture, institutions, and society by generalising its authoritarian values, which are in essence anti-social and destructive of politics (Omeje, 2020). The civil military relation during those military rules was what El-Shimy (2016) called "Praetorianism"; a political system where civilians serve in government at the pleasure of the army. Praetorian armies are foundational: they establish the political system and all its rules, usually following a coup d'état against civilian political actors to accomplish goals of societal demobilization, political organization and the writing of a new founding constitution for the country (El-Shimy, 2016). Nordlinger cited in El-Shimy (2016) noted that praetorianism is the opposite of civilian control; thus, military control would be more apt.

The foregoing conditions are the exert description of the Nigerian civil military relation during the 29 years of military rules. They came through coup d'états; civilians serve at their pleasure; the changed Nigeria political system from parliamentary to presidential system; changed Nigerian federalism from four regions to thirty-six state and seven hundred and seventy-two local governments and wrote a new constitution. Consequently, Nigeria civil military relation at that realm was the opposite of civilian control: military control.

The Fourth Republic (1999-date) which supposed to be hallmarked with democratic civil-military relation; had rather been characterised by military's poor human rights record with debilitating impact on her effectiveness and reputation. From the serious abuse of civilian communities in Odi in 1999 and Zaki Biam in 2001; to extrajudicial killings of members of the Islamic Movement of Nigeria (IMN) in Zaria and Abuja; and the Indigenous People of Biafra (IPOB), These acts alienate citizens, whose cooperation is crucial for successful internal security operations (DFAT, 2018: p. 25) and

(https://www.crisisgroup.org/africa/west-africa/nigeria/nigeria-challenge-militar y-reform 2016); to killing (of) protesters at Lekki killing (tollgate)Lagos state; in Obigbo (2020) and Orlu in 2021 (Intersociety, 2020; Egbas, 2021; Uneze, 2021).

The following graphs (Figures 1-3) are brief insight into the human right abuses, NA has perpetuated, as stated earlier the human rights abuses are well documented in literatures especially by Amnesty International and other Human Right Watch groups.

\section{Theoretical Perspectives}

This paper uses the Feaver's Principal Agency (PA) civil military theory. Arising 


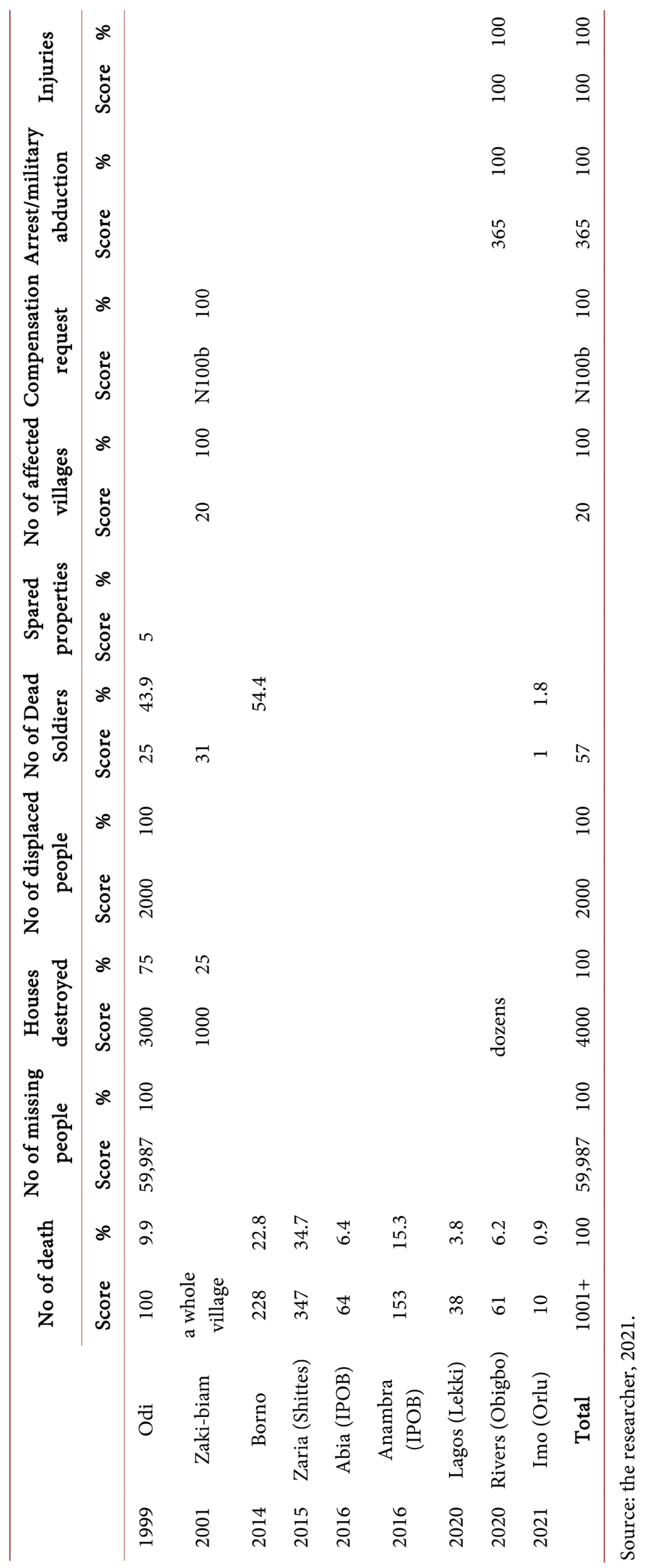

Figure 1. Table of Analysis of extra judicial killings and wanton human rights abuses in Nigeria. 


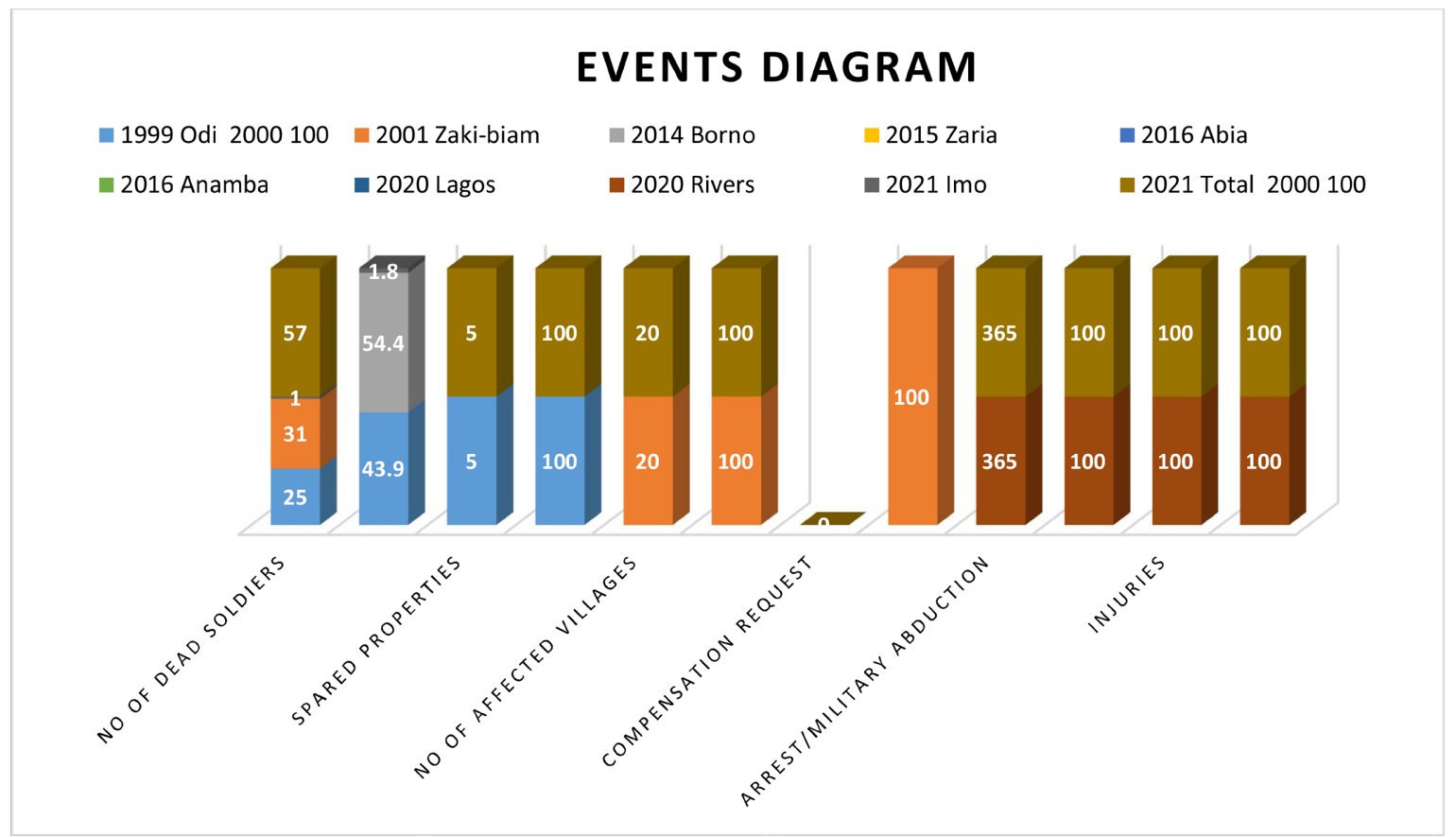

Source: the researcher, 2021.

Figure 2. Events Diagram.

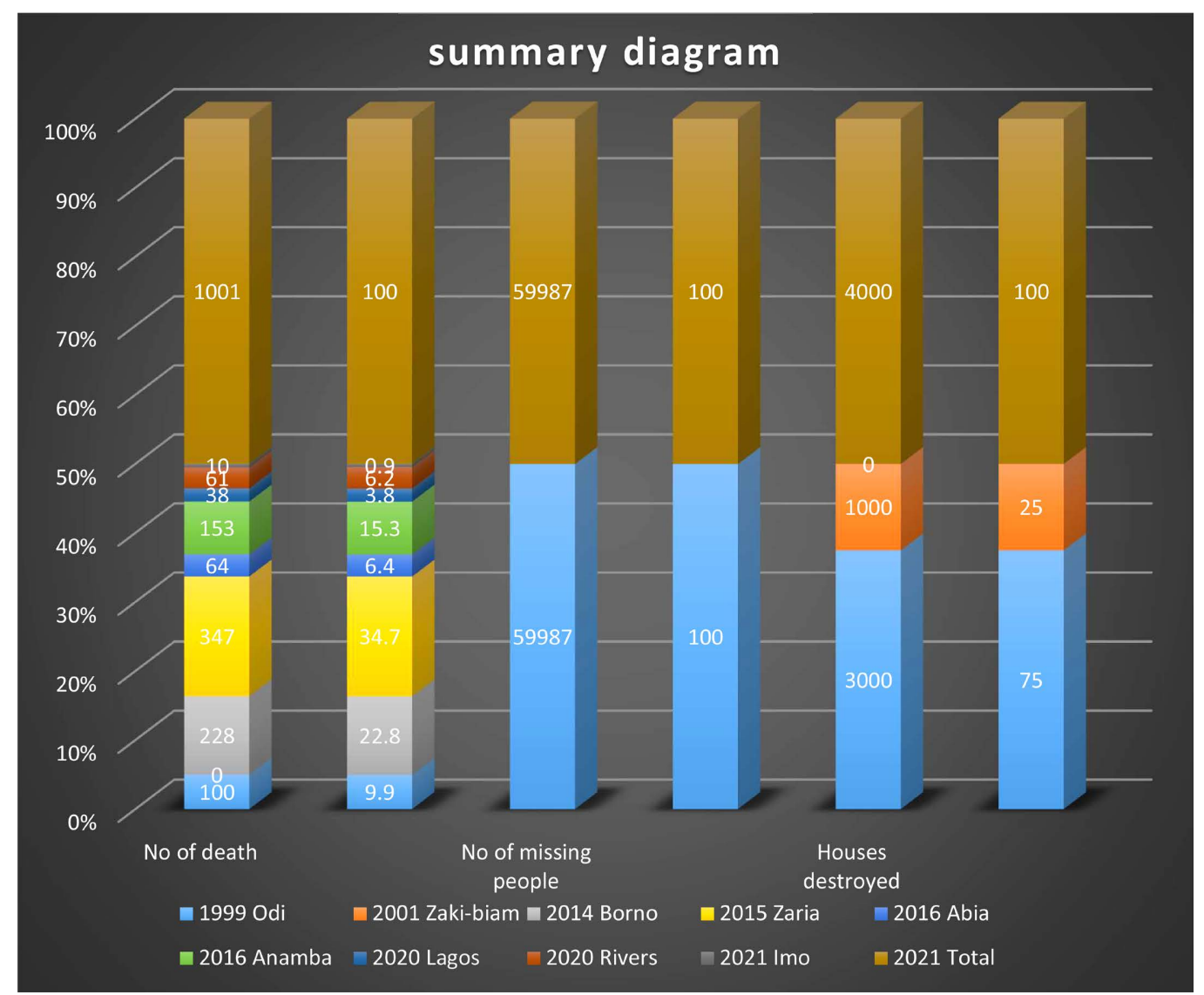

Source: The researcher, 2021.

Figure 3. Summary Diagram. 
from the thesis of this paper, the temptation would have been to use Janowitz's model of constabulary force of shared value with the society. However, Feaver builds a model that addresses problems between actors (principals/government) and their subordinates (agents/army), which can be liken to the employer-employee relationship (Baker, 2007). The goal is to address the problem of how the employer (government elected by the people) ensures that the employee (the army, an agent of government) does what is required of her-working (submission) rather than shirking (refusal to obey or obey in breach). It is a strategic interaction between principals and their military servants; the military is working when it diligently seeks to fulfil the wishes of its civilian overseers, it will be shirking if its works do not correspond with the desires of the civilian principal, like human rights abuses during operations which breaches international regimes on military operations.

Feaver (2005) described the problem of getting the agent to work in the desired manner-like working in tendon IRs rules as a moral hazard problem. $\mathrm{He}$ noted that in literature, there are two distinct ways to solve this problem: 1) to ensure that the agent is working by applying the best available monitoring system--intrusive or non-intrusive instruments, or both; 2) that the superior approach is to implement measures aimed at adjusting the agent's preferences to increasingly coincide with those of the principal, which can be measured and assessed, especially in terms of the attempt to seek convergence between the preferences of the civilian principal and the military agents and mechanisms for addressing the constantly-threatened imbalance in the civil-military relationship (Baker, 2007), which is akin to the government which is elected by the people seeking a convergence where the military will no longer abuse the rights of her citizens and attract the wrath of other states by breaching IRs rules.

Though the Feaver model has been criticised of imposing economic model on a relationship between a state and one of its strongest institutions, the army. Also, it is criticised that the more reassurance the principal provides the less credible their threat of sanctions becomes, and vice versa: a principal whose commitment to support the agent is unshakable encourages the agent to take advantage and shirk with less fear of penalty. And problems of interest asymmetry, information asymmetry, and moral hazard thus impose an inherent agency loss, or divergence between the outcome the principal seeks and what it actually gets (Biddle, 2017), which means in a state like Nigeria, the government support for the military despite its human rights abuses, encourages the military, even though military and the state have divergent of interests, like: the military wants higher budget, while the state wants efficiency to enable her solves other problems and the military does not want to take risk, thus it wants to always use maximum force to achieve its goal with minimum risk.

Another criticism is that it concluded that it can only be applied in mature democracies (Baker, 2007). However, Baker (2007) also noted that where civilian governments have few resources with which to apply coercive power over military agents, these civilian governments can still put into place both monitoring 
and punishment mechanisms, by means of its involvement in regional organisations, like the African Union (AU) and the Southern African Development Community (SADC).

Consequently, in a democracy like Nigeria, with principle of democratic governance the rights of citizens to protest, assemble etc. are guaranteed; and even more cemented by the rise of concepts such as the Doctrine of Humanitarian Intervention (DHI), the International Humanitarian Law (IHL); International Human Rights Law (IHRL); African Union (AU), Constitutive Acts and Economic Community of West African State (ECOWAS) protocol on uses of force. These are regimes that guide conducts on military operations. And when the army goes contrary to these regimes; it goes against the interest and will of the polity and alienates citizens, whose cooperation is crucial for successful internal security operations; as events in Zaria and Abuja with Shiites; Southeast with IPOB and the EndSARS shooting at Lekki portray.

Feaver proffered, a wide range of corrective options available to democratic governments, among which are devising strategy, drawing up operational plans, directing the equipping and provisioning of the military, and setting rules of engagement; as means corrections (Feaver, 2005: pp. 90-93). This means that the Nigerian government devise strategy and proviso on how the military can engage in internal operation without much human rights abuses. Therefore, Feaver model of analysis is fitting in interrogating the Nigeria military internal operations and its insistent military human rights abuses.

This paper relied on documentary method of data collection. It is most suitable for the paper because the data required for the study are already in the public domain. What is needed is to refine, interpret, evaluate, and analyze them. The paper also used content analysis, rooted in systematic logical deductions; a method for analyzing and/or retrieving meaningful information from documents and other contents. The next section discusses international military operational regimes.

\section{Military Operational Regimes}

During the Cold War era, focus and emphasis were on national security, which were detrimental to the security of individuals, as human rights violations by regimes supported by the West demonstrated (Huggins, cited in Friesendorf, 2012). However, in the post-Cold War period, societies and individuals have now taken the centre stage on security. This is in sequel to the reconceptualization of sovereignty, which now puts the governments of liberal democracies under pressure to intervene whenever human rights are wantonly violated on the auspices of humanitarian intervention and Responsibility to Protect (R2P). However, when they are reluctant to do so; NGOs, journalists, public intellectuals, and the $C N N$ effect (impact of public opinion on the foreign policies of liberal democracies) are quick in pointing the finger at government's unwillingness to intervene (Friesendorf, 2012). 
Indeed, the revolution in telecommunication has made the world a global family, thus within minutes, records of human rights abuses perpetuated in any part of the world are made available to the world through the social media and civil societies. The core of modern democratic state in internal and external security, crime and war, and police and military work is proportionality, which is an obligation under international law and it is also enshrined in constitutions and domestic laws of democracies. Appropriate force must be used at the appropriate time to win the hearts and minds of citizens. Maximum, indiscriminate force is ineffective and counterproductive (Friesendorf, 2012). Proportionality is guided by rules, which Friesendorf (2012) divided into formal and informal: constitutions, laws, regulations, doctrines and rules of engagement; and the later are norms that enable or constrain the use of force, which results from positive or negative experiences with the use of force in the past; Peter Katzenstein cited in Friesendorf (2012) extended it to studies on norms, of strategic, political and organisational culture, which reveal how ideational factors influence policy. In Nigeria, the constitution guarantees right to life, and Nigeria is a signatory to organizations with IRs that prohibits and sanctions human rights abuse. In Nigeria even NA knows that it is notorious for human right abuses.

Actually, multilateral rules and doctrines of engagement, which this paper considers as international operational regimes are exemplified first at the African level where, Ebo (2005) stated that the draft Code of Conduct (CoC) for Armed and Security Forces in Africa, drawn up in 2002, is an effort to fill the expanded democratic control of the armed and security forces, with following: parliamentary oversight, a vibrant and resilient civil society, and a free press. The $\mathrm{CoC}$ in its regulatory framework governing civil military relations, Chapter 1, Articles (5/9/10/11/13/); Chapter 3, Article (21/22/23) in (http://www.unrec.org/eng/Workshop.htm) stated that:

The personnel of armed and security forces shall assume responsibility for individual acts that violate international humanitarian law and human rights; the behaviour of armed and security personnel shall show respect for international humanitarian law, human rights and pertinent national laws; no order which is at variance with international humanitarian law, human rights and pertinent national law shall be given to or executed by armed and security personnel; the civilian, political and administrative authority shall ensure that the military operations it orders, including operations to maintain internal peace and order, shall be executed in conformity with the relevant provisions of international humanitarian law, human rights, national laws and this Code of Conduct; under no circumstance shall the civilian, political and administrative authority resort to armed and security forces to restrict the peaceful, legitimate and legal exercise of the individual and collective rights of the citizens as conferred by the Constitution; armed and security forces are to show respect and provide protection and assistance to the civilian population...in times of armed conflict...in collabora- 
tion with the government, civil society, including non-governmental organisations and the media, endeavour to inform and educate the public on their unclassified programmes and operations.

Meanwhile, the Human Rights, International Humanitarian Law, and its Implementation Chapter IV (27/28/30/31/32) and V (33) enjoined the following:

...in addition to their occupational training, shall be given the appropriate education in constitutional law, human rights, international humanitarian law... Civilian and politico-administrative authority, personnel of armed and security forces and their commanders, shall be held individually responsible for instructions, orders and/or actions in violation of human rights and international humanitarian law... as state of emergency, state of siege... as defined by the Constitution, armed and security forces shall conform with national law and international humanitarian law... shall refrain in all circumstances from the following acts: murder, torture, corporal punishment, rape, mutilation, cruel, inhumane and degrading treatment, hostage taking, collective punishment... internal law and order, armed and security forces shall use firearms as a last resort with maximum restraint, respecting the principle of minimum force, even in situations of self-defence... in event of injuries, the personnel of armed and security forces shall assist the wounded without discrimination... families ... informed... shall be integrated in the training and educational programmes and taught to the armed and security forces of all Member States of the African Union

(http://www.unrec.org/eng/Workshop.htm).

Correspondingly the AU constitutive Act, Article 3 (e, g, \& h) and 4 (h, m \&p); which dealt with the objective of the Union emphasised the taking of due account of the Charter of the United Nations and the Universal Declaration of Human Rights which is also domiciled in African Charter on Human and Peoples' Rights and other relevant human rights instruments, which promote and respect democratic principles and institutions, human rights and the rule of law; and that the Union has the right to intervene in a Member State pursuant to a decision of the Assembly in respect of grave circumstances, namely: war crimes, genocide and crimes against humanity.

Globally, IHL and IHRL are complementary bodies of international law that champion protection of lives, health, and dignity of individuals, from different angles. They prohibit torture, discrimination, or cruel treatment, prescribe basic rights for people subject to criminal process (Leader, 2000). According to International Committee on Red Cross (ICRC) Report (2021 \& 2004), there was the debate whether the right not to be arbitrarily deprived of one's life applied also in hostilities, however in 1996 the International Court of Justice observed that the International Covenant on Civil and Political Rights did not cease in times of war and that, in principle that it is determined by the applicable lex specialis (the law applicable in armed conflict) (ICRC, $2004 \&$ 2004). This settled the debate 
on the application of IHL and IHRL implying that the later apply at all times (lex generalis); in conflict, the later prevails.

IHL also imposes on individuals the responsibility and accountability for any breach of war crime in non-international conflicts, which the International Criminal Court adjudicates. The duty to implement IHR and IHRL rests first on states to ensure compliance; they can also act in co-operation with the United Nations (UN). International Red Cross and Red Crescent Movement can also initiate actions deemed necessary to ensure faithful application of IHL (ICRC, $2003 \& 2004)$.

The next section discusses Nigeria Army Civil Military Reforms.

\section{Nigerian Army Civil Military Relations Reforms}

Indeed, the greatest ornate inward initiated reforms of the NA to win the hearts and minds of the citizenry was the Transformation Agenda, (2010-2014) by Lt. Gen. Onyeador Azubuike Ihejirika. The reform was to re-gig the NA in tune to the contemporary challenges it faces and to correct its historic public relations disaster, the NA established a new systems-level Department of Civil Military Affairs (DCMA) to inter-face with civil societies. In 2013, it established the Defence Radio 101.7 FM station to tell its own story and an online press release platform called PRNigeria.com (a news bank) for national security reporters, where it deployed several military and civilian (cyber-warriors) to prowl and represent its perspectives on several new social media platforms and online discussion sites. Thus, the NA began to genuinely cultivate good rapport with large segments of Nigerians that still bears scars and bitter memories of repression by the military (Iheduru, 2017).

The Centre for Lessons Learnt in the Nigerian Army Transformation and Innovation Centre (NATIC) at the AHQ, was also established to harness important lessons learnt in various operations conducted by the NA or other countries armies. It reviewed existing training manuals and published new ones to reflect the changing security environment, which was codified into the Code of Conduct for Nigerian Armed Forces Personnel on Internal Security \& Aid to Civil Power Operations that enjoins military personnel to be impartial arbiters amongst their host communities while also maintaining good civil-military relations with them. These outfits and networks regularly put out films, dedicated public relations and online news blogs, documentaries, and radio jingles (radio is still hugely popular among the local population in northern Nigeria) to sensitize Nigerians on its activities. The Centre for Crisis Communication, founded in 2015, a collaborative project of about 17 government agencies (military, Department of State Security Services, the National Intelligence Agency, Police, Economic and Financial Crimes Commission and other) was established as a systematic approach to information management and response organ. NA also partnered with the Nigerian Bar Association to establish a human rights team to monitor and report human rights violations by soldiers and Human Rights Desk under 
the DCMA, headed by a female army lawyer (Iheduru, 2017).

Meanwhile, Omeje (2020) eulogised Lt Gen Tukur Buratai, Chief of Army Staff (2015-2021) as one who placed civil-military relations on the front burner. He stated that Gen Buratai demonstrated that CMR transcended information management, that it demands the highest level of community relations' competencies and actions that involve effective communication, respect for human rights, rule of law, negotiation and conflict management skills, accountability as well as responsiveness. To him, for the NA to win the hearts and minds of the Nigerians, it embarked on several quick impact projects and humanitarian services such as: building of clinics and provision of some medical services, they also constructed schools, roads and bridges and sunk boreholes and cleared gutters for communities. Occasional reports of misuse of power or overzealousness of military personnel were promptly sanctioned, e.g. a crippled in Onitsha was beaten by soldiers and the soldiers were court marshalled and sentenced for their gross misconduct.

Meanwhile, rather than winning the hearts and minds of citizens, Gen. Buratai will go down in history as the army chief whose tenure witnessed the highest human rights abuses in Nigeria. He massacred 347 of Shiites in Zaria (burying them in two mass burial) for blocking his rights of way; and tens of others in the streets of Abuja. Under his watch the army cold-bloodily shot and killed Nigeria National Anthem singing and Flag waving peaceful protesters at Lekki, Lagos: killing scores. Under his watch, NA militarised a peaceful IPOB to a militant group that engaged the army in a gun duel in Orlu, killing soldiers in January 2021. According to El-Abdallah (2021), The International Criminal Court has said that the matter of the trial of the outgone Chief of Army Staff, Lt Gen Tukur Buratai; former Chief of Defence Chief, General Abayomi Olonisakin; former Chief of Naval Staff, Vice Admiral Ibok-Ete Ibas; and former Chief of Air Staff, Air Marshal Sadique Abubakar, is with its prosecutor (http://saharareporters.com/2021/01/29/exclusive-int\%E2\%80\%991-criminal-cou rt-confirms-buratai-other-sacked-military-chiefs\%E2\%80\%99-cases-their?s=09).

Therefore, though there was effort on the side of the army to launder her image through these civil-military relations programmes, but their effort failed.

In the next section the paper discusses the case for a Nigerian Army Constabulary Corps.

\section{The Case for an Army Constabulary Corps}

Indeed, it was Plato who described soldiers as guardians (people's army), which exist for those ends that all in society share and which pursuit and protection enhance the ability of all to live according to their lives' plans. Soldiers are part of the rest of the society in an ideal situation and should not have interests that are incompatible with those of the rest of the society for which they exist and are trained to defend. Their training should include indoctrinating them about the values, interests, and goals of their society, since they are agencies for attaining 
their interest. The centrality of the military was further strengthened by Thomas Hobbes, who wrote "covenants without swords are but words" and Machiavelli in The Prince, affirmed that "the chief foundations of all states, whether new, old, or mixed are good laws and good arms ... best ordinances in the world will be despised and trampled underfoot...if not supported... by military power; they are like a magnificent, roofless palace which, though full of jewels and costly furniture, must soon moulder into ruin, since it has nothing but its splendour and riches to defend it from ravages of the weather ( Plato, Hobbes and Machiavelli cited in Ojo, 2000: pp. 1-2).

Certainly, no state can exist without the military. Though the military is one of the institutions of the state, if not well subordinated to rules; it can truncate the state. The army is essentially trained to use maximum force to subdue, subjugate and conquer enemy targets. Ibrahim (2017) noted that Nigeria constitution defines the purpose of the state as the protection and security of Nigerians and the pursuit of their welfare.

The National Security Adviser to the President stated that there are military operations in 32 out of the 36 states of Nigeria; meaning that the normal process of the police being in charge of internal security no longer operates. The military is not traditionally trained to engage in this arena and their rules of engagement might not be suitable for the new role thrust upon them (Ibrahim, 2013). That is why when NA is faced with protesting citizens like Shi'ites at the outskirts of Abuja or \#EndSARS at Lekki or when sent to quell internal crisis in Odi or Zaki Biam; they resorted to serious abuse of civilian communities with live ammunition, bazooka, and other high weaponry, which alienate the citizens. Also, for a Country of over 200 million facing several security challenges, a military numbering less than 120,000 personnel (all services) is clearly inadequate to face the type of daunting challenges it faces (Ibrahim, 2013).

Indeed, to effectively engage in internal security and win the hearts and minds of the citizenry the NA needs to re-calibrate its uses of force to the problem at hand rather than maximum and indiscriminate use of force that have been ineffective and counterproductive. Friesendorf (2012) noted that there are three levels of force: maximum, intermediate, and minimum and that though internal security requires all three levels, at each level they are to show versatility and the ability to adapt their material, educational, cultural, legal, organisational, and operational characteristics, and thus levels of force, to their environment. He further stated that for the army to be versatile, soldiers would have to avoid relying on lethal weapons as a default weaponry: have to talk first, appear less martial, consider legal obligations beyond the laws of war, operate in smaller units and work closely with the public. And for regular police officers to move towards versatility, they would have to be comfortable with weapons such as automatic rifles, be prepared for the use of lethal force, demonstrate a martial attitude, understand military laws and regulations, operate in larger units and switch from crime fighting to combat if necessary. The Nigerian police has demonstrated this type of versatility in its Mobile Police Unit and Special 
Anti-Robbery Squad (SARS) now Special Weapons and Tactics Team (SWAT).

The need for such a medium and versatile force has been glaring since the 1980s. Ergo, the then military President of Nigeria Gen. IB Babagida, considering the escalation of conflict to a war scenario whenever there was a border clash between the Nigerian army and the Cameroonian Gendarme (a medium force); and to fill this gap, he established the Nigerian National Guard in 1991, which Gen S. Abacha later disbanded. In a Vanguard editorial (November 9, 2010), President Goodluck E. Jonathan mooted the idea of re-establishing the National Guard to take care of civil unrests, kidnapping, electoral violence, illegal oil bunkering, and vandalization of oil and gas facilities and militancy in the oil producing areas.

The Editorial emphasised that as much as they recognised the need for Nigeria to rise up to the challenges of modern-day security management, they were worried that the resort to the establishment of a National Guard is just another badly chewed and ill-digested strategy, which will lead to another round of wasteful spending. That there was no need setting up another federal security agency when we already have the Army, Air Force, Navy, Nigeria Police Force, State Security Service, Customs, Immigrations and the National Security and Civil Defence Corps. It further asked what was the point in adding to the constraints security agencies face when government is struggling to fund existing ones? What would the National Guard do that the existing agencies, if better funded, cannot handle? The Vanguard editorial declared:

If the issue is terrorism, for instance, a branch can be created within the police to receive specialised training in tackling terrorism. Communities are also best placed to know the criminals among them. Our current chain of command for security agencies that places everything under Abuja cannot enhance security. It is cumbersome, makes decisions difficult to locate and inhibits proper policing of the country. The creation of the National Guard is not only unnecessary, but it is wasteful in the same way that a Ministry of Homeland is a duplication of the Ministry of Interior (November 9, 2010: p. 12).

There is a dichotomy between external military threats and internal crime problems which mitigate against maximum force in the domestic realm. The constitutions and laws of democracies emphasise the rule of law and norms such as proportionality; the disproportionate use of force against citizens undermines public support. Political parties, especially those in the opposition, want to ensure that the government respects constitutional provisions regarding the deployment of the military. Just like the Peoples' Democratic Party (PDP) has stridently called on the ICC to try General Buratai and other Service Chiefs he worked with for gross breach of IHL, IHRL, AU Constitutive Acts, African Charter of Human Rights, and other international military operational regimes. Gross violation of citizens' rights was the excuse given for the invasion of Libya in 2010, which led to the death of President Gaddafi and some of his children. His 
son and top aides were declared wanted by ICC. Today, a once prosperous Libya is a failed state and an arena for great power rivalry, the same with Syria, now a theatre of all manners of great powers rivalries.

Gannon (n.d.) gave a narration of the Royal Irish Constabulary (RIC) which was tasked to fight Irish insurgency but was disbanded in the Spring of 1921, because of its recourse to communal retaliation for IRA attacks, which made Britain lose the propaganda war critical to its counterinsurgency's success. In April 1922, over 700 disbanded RIC members were transferred to Palestine as the British section of the Palestine Gendarmerie, a striking force/riot squad formed to reinforce the locally recruited policing forces. Due to lesson learnt in her misadventure in Ireland, its retaliation for attacks on her, now was targeted only at the perpetrators and, even in cases where gendarmes were killed, revenge was not wreaked on the wider Arab population. Its function was to maintain public order and fight against brigandage: highway robbery and raiding by armed bands, which casted the British Gendarmerie as a counterinsurgency force; it made a success of its goals (Gannon, n.d.).

In the Philippine, her Constabulary officially constituted the national police force and essentially operated as a gendarmerie, it was responsible for dealing with large-scale crime, conducting wide-area operations, and enforcing the peace and national laws, especially in remote areas where other forces were non-existent or ineffective. The constabulary also played a prominent role in combating the Moro and communist insurgencies (Philippine: Philippine Constabulary, 1991, http://www.country-data.com/cgi-bin/query/r-10522.html).

Meanwhile, the argument for a Constabulary Corps for NA is premised on the exploit a similar outfit, the United States of America Constabulary army, which became fully operational on 1 July 1946 made amidst the disorder of post-war Germany. Its arsenal includes armoured cars, tanks, jeeps, motorcycles, and other vehicles outfitted with full radio and signal equipment. It was a highly mobile force, ready and able to respond to general and specific needs while policing places like Displaced Persons (DP) camps, suppressing riots, confiscating weapons and contraband. It has a horse cavalry platoon and motorcycle platoon. The horse cavalry platoon was designated to work in riot suppression and crowd control, just as modern policing agencies use horse mounted police officers today. They were also used in wooded areas and other locations inaccessible to motor vehicles. The Constabulary was organized along the geo-political boundary in the occupied zone. The regiments, squadrons and troops carried this presence down to the smaller political boundaries (Kaufman, n.d., https://armyhistory.org/mobility-vigilance-justice-the-u-s-constabulary-forces-i n-germany-1946-1952).

Ebo (2005) noted that at the core of civil-military relations is the control and regulation of the armed and security forces by the larger society, based on the principles of transparency and accountability; to have an armed and security forces which are effective and efficient in the performance of their constitutional duties and according to the dictates of democratic governance. He defined de- 
mocratic control as the civilian oversight of the military by a legitimate, democratically elected authorities of the state, in a manner consistent with the basic tenets of transparency and accountability; key principles of democratic control are: accountability of security forces to elected civil authorities and civil society; adherence of security forces to international law and domestic constitutional law; and the capacity within civil society to monitor security sector and provide constructive input into political debate on security policies in a conducive environment, among others.

Meanwhile, Feaver pointed out that, in structural terms, the desires of the civilian principal can be viewed in two-fold distinction: functional goal, whether the military is competent (measured by some reasonableness standard) to do what civilians asked it to do; and relational goal—where the military is engaging in any behaviour that undermines civilian supremacy in the long run, even if it is fulfilling civilian functional orders (Feaver, 2005: p. 61; Baker, 2007). He described the problem of getting the agent to work in the desired manner as a moral hazard problem. Feaver noted that in general literature there are two distinct ways to solve this problem: 1 ) to ensure that the agent is working by applying the best available monitoring system, intrusive or non-intrusive instruments, or both;2) that the superior approach is to implement measures aimed at adjusting the agent's preferences to increasingly coincide with those of the principal (cited Baker, 2007).

Indeed, situating the foresaid Feaver PA tenets to the NA, functionally they look talented to do what the democratic leadership asks them to do; relationally, the Nigeria army has shown in Odi, Zakim Biam, with Shittes, with IPOB and at Lekki that in carrying out its functions, it has been undermining the democratic ethos and control of the army. To get this Agent (army) in line with key principles of democratic control: accountability of security forces to elected civil authorities and civil society; adherence of security forces to international law and domestic constitutional law; and the capacity within civil society to monitor security sector and provide constructive input into political debate on security policies, in a conducive environment. Feaver proffered, a wide range of corrective options available to civilians, among which are devising strategy, drawing up operational plans, directing the equipping and provisioning of the military, and setting rules of engagement as among the means civilians can employ to achieve the goal of correction (Feaver, 2005: pp. 90-93 cited Baker, 2007).

Therefore using Feaver model of analysis, the paper argues as a correctional remedy to the incessant human rights abuses by NA, for the establishment of a NA Constabulary Corps, which shall be a kind of medium force branch of the army, with specialty in all manners of internal security operations; and well-schooled in international security operational regimes.

The Nigerian police has a miniature of such functional unit in their Traffic Warder Unit, which specialise in traffic control, with its men coming from the area they operate. That the Nigeria Army are now in thirty-two out the thirty-six states of Nigeria have made this branch of army apparent and obvious. Their of- 
ficer corps shall be military officers well trained in democratic and international security operational regimes. Its men shall be recruited from their area of deployment: Army Divisions and army units in the 36 states of Nigeria. Apart from medium forces weaponry, it shall have all equipment for the control of protest, crowd, and riot: baton, hot water spray vehicles, pepper spray, tear gas, mobile perimeter fencing and others. The Nigerian army has the intellectual reservoir to give it all its finesse and make it suitable to Nigeria's security problems and environment and NA unlike the police is far advance in maintenance culture, logistics storage, deployment, and communications.

\section{Conclusion}

The Fourth Republic (1999-date) which supposed to be hallmarked with democratic civil military relations, has rather been characterised by military's poor human rights record with debilitating impact on her effectiveness and reputation. The poor human rights records are, but not limited to the followings: serious abuses of civilian communities in Odi (1999) and Zaki Biam (2001); to extrajudicial killings of the Islamic Movement of Nigeria (IMN) in Zaria and Abuja; and the Indigenous People of Biafra (IPOB), the abuses continued in killing of protesters at Lekki, Lagos state; Obigbo, Rivers state (2020) and Orlu, Imo state in (2021). These have alienated citizens, whose cooperation is crucial for successful internal security operations.

Post-Cold War security practices centre on human security, humanitarian intervention and Responsibility to Protect (R2P); with multilateral rules and doctrines of engagement, which this paper considers as international operational regimes. They are exemplified in the draft Code of Conduct $(\mathrm{CoC})$ for Armed and Security Forces in Africa, parliamentary oversight, a vibrant and resilient civil society, and a free press. Globally, there are IHL and IHRL, and complementary bodies of international law that share some of the same aims: protection of lives, health, and dignity of individuals. All prohibit torture or cruel treatment, prescribe basic rights for persons subject to criminal process, and prohibit discrimination. It must be noted that gross violation of citizens' rights was the excuse given for the invasion of Libya in 2010.

There is a dichotomy between external military threats and internal crime problems which mitigate against maximum use of force in the domestic realm. Indeed, the need for a medium and versatile force caused Gen. IB Babagida, in 1991 established the National Guard. President Goodluck E. Jonathan mooted the same idea in 2010. The Nigerian army functionally is capable to do what the democratic leadership asks it to do; relationally, the Nigeria army has shown in Odi, Zakim Biam, with Shittes, with IPOB and at Lekki that in carrying out its functions, it is undermining the democratic control of the army by grossly abusing the rights of Nigerian citizens.

To get this Agent (army) in line with key principles of democratic control, this paper advocates for the establishment of a NA Constabulary Corps, a medium 
force branch of NA with specialty in internal security of all manners; wellschooled in international security operational regimes and its men drawn from their area of operation.

\section{Conflicts of Interest}

The authors declare no conflicts of interest regarding the publication of this paper.

\section{References}

Ake, C. (1995, September 25). A Plausible Transition. Tell Magazine.

Baker, D.-P. (2007). Agency Theory-A New Model of Civil-Military Relations for Africa? https://www.accord.org.za/ajcr-issues/agency-theory/

Biddle, S. (2017). Building Security Forces \& Stabilizing Nations: The Problem of Agency. Daedalus, the Journal of the American Academy of Arts \& Sciences, 146, 126-138.

DFAT (Department of Foreign Affairs and Trade) (2018, March 9). Country Information Report Nigeria. Australian Government Department of Foreign Affairs and Trade. https://www.dfat.gov.au/sites/default/files/country-information-report-nigeria.pdf

Ebo, A. (2005). Towards A Code of Conduct for Armed and Security Forces in Africa: Opportunities and Challenges. Geneva Centre for the Democratic Control of Armed Forces (DCAF). http://www.dcaf.ch

Egbas, J. (2021, January 26). Why Were Soldiers Shooting on the Streets of Orlu Imo State? Pulse Explainer.

https://www.pulse.ng/news/local/orlu-shooting-by-soldiers-pulse-explainer/n2h3dhy

El-Abdallah, F. (2021, January 29). Criminal Court Confirms Buratai and other Sacked Military Chiefs Cases. Sahara Reporters.

http://saharareporters.com/2021/01/29/exclusive-int\%E2\%80\%99l-criminal-court-conf irms-buratai-other-sacked-military-chiefs $\%$ E2\%80\%99-cases-their?s=09

El-Shimy, Y. (2016, June). A Model of Praetorian States: The Military and Egypt's Failed Transition (2011-2013). http://www.belfercenter.org/MEI

Enyiazu, C. (2018). Federalism and the Resurgence of Biafra Separatist Movements inNigeria. In South-East Nigeria Political Science Association (NPSA) Conference.

Enyiazu, C., Nwangwu, C., \& Madueke, O. (2021). Policing in Nigeria 'Troubled' Federation: Interrogating the 'Ostriching' of the Nigeria Governing Elites. Maiden Edition, Abia State University Journal of Social Sciences, 129-150.

Feaver, P. D. (2005). Armed Servants: Agency, Oversight, and Civil-Military Relations. Harvard University Press.

Friesendorf, C. (2012). International Intervention and the Use of Force: Military and Police Roles. Ubiquity Press, Geneva Centre for the Democratic Control of Armed Forces. https://doi.org/10.5334/bbo

http://www.dcaf.ch

Gannon, S. W. (n.d.). The Royal Irish Constabulary and Colonial Policing: Lessons and Legacies.

https://www.rte.ie/centuryireland/index.php/articles/the-royal-irish-constabulary-andcolonial-policing-lessons-and-legacies

Ibrahim, J. (2013). The Norms for Civil-Military Relations in Nigeria. Premium Times. https://www.premiumtimesng.com/opinion/147394-norms-civil-military-relations-nig eria-jibrin-ibrahim.html 
Ibrahim, J. (2017). Improving civil-military relations in Nigeria. Centre for Democracy and Development.

Iheduru, O. C. (2017). Political Culture and Military Professionalism in Nigeria.

International Committee on Red Cross (2004). What is International Human rights Law. https://www.icrc.org/en/doc/assets/files/other/what is ihl.pdf

International Committee on Red Cross (2021). International Humanitarian Law and International Human Rights Law.

https://www.icrc.org/en/document/international-humanitarian-law-and-internationalhuman-rights-law-similarities-and

Intersociety. (2020, November 19). \#EndSARS: IPOB killed 6 soldiers and 4 policemen, burnt police stations. The Nigerian Voice.

https://www.thenigerianvoice.com/news/293885/nigeria-over-60-30-identified-now-kil led-90-100-50-ide

Kaufman, D. A. (n.d.). Mobility, Vigilance, Justice: The U.S. Constabulary Forces in Germany, 1946-1952.

https://armyhistory.org/mobility-vigilance-justice-the-u-s-constabulary-forces-in-germ any-1946-1952/

Leader, K. (2000). The Principles of Humanitarian Action in International Humanitarian Law. Humanitarian Policy Group (HPG).

http://www.odi.org.uk.hpg.publications

Ojo, E. O. (2000). The Military and Democratic Transition in Nigeria: An Indepth Analysis of Gen. Babangida's transition Program (1985-1993). Journal of Military and Political Sociology, 28, 1-20.

Ojo, E. O. (2009). New Missions and Roles of the Military Forces: The Blurring of Militaryand Police Roles in Nigeria. Journal of Military and Strategic Studies, 11.

Omeje, C. (2020). General Buratai and Civil-Military Relations in Nigeria. https://nigeriannewsdirect.com/general-buratai-and-civil-military-relations-in-nigeria/

Philippine: Philippine Constabulary (1991). http://www.country-data.com/cgi-bin/query/r-10522.html

Salihu, N. (2017, February 26). The Colonial Legacy of Civil-military Relations and Democratic Stability Iin West Africa.

https://www.accord.org.za/conflict-trends/colonial-legacy-civil-military-relations-dem ocratic-stability-west-africa/

Uneze, A. (2021, January 26). 10 Feared Killed in Military, IPOB Clash in Imo. ThisDay. https://www.thisdaylive.com/index.php/2021/01/26/10-feared-killed-in-military-ipob-c lash-in-imo/

Vanguard Editorial (2010, November 9). No to National Guard. https://www.vanguardngr.com/2010/11/no-to-national-guard/ 